\title{
Effect of a Phorbol Ester on Immunoreactive Endothelin-1 Release from Cultured Porcine Aortic Endothelial Cells
}

\author{
Yoshiyuki HATTORI, Kikuo KASAI, NobUyuki BANBA, \\ SAchiko HATTORI, Tsutomu NAKAMURA, AND SHIN-ICHi SHIMODA \\ Department of Endocrinology, Internal Medicine, Dokkyo \\ University School of Medicine, Tochigi 321-02, Japan
}

\begin{abstract}
This study was designed to examine how protein kinase C (PKC) regulates the release of endothelin-1 (ET-1) from cultured porcine aortic endothelial cells. We measured the release of immunoreactive (IR)-ET-1 from cells cultured for up to $72 \mathrm{~h}$ in the presence or absence of a phorbol ester TPA. The release of IR-ET-1 from control cells (no TPA) increased according to time for up to 72 $\mathrm{h}$. In the presence of TPA, the release of IR-ET-1 from the cells was higher than the control level for up to $8 \mathrm{~h}$, but was lower thereafter and reached a plateau after $48 \mathrm{~h}$. TPA dose-dependently stimulated IR-ET-1 release during incubation for $4 \mathrm{~h}$, but suppressed it after incubation for $72 \mathrm{~h}$. Stimulation of PKC by diacylglycerol mimicked the early $(4 \mathrm{~h})$ action of TPA. On the other hand, pretreatment of cells with TPA to downregulate PKC significantly suppressed basal and thrombin- or FCS-stimulated IR-ET-1 release. These findings suggest that the activation of PKC is related to the stimulation of ET-1 release and that down-regulation of PKC leads to the suppression of ET-1 release from cultured endothelial cells.
\end{abstract}

Key words: Endothelial cells, Endothelin-1, Phorbol ester, Protein kinase C.

(Endocrinol Japon 39: 341-345, 1992)

ENDOTHELIN (ET) is a peptide with a potent vasoconstrictor action that was isolated by the purification of supernatants from cultured porcine endothelial cells [1]. A potent activator of protein kinase $\mathrm{C}(\mathrm{PKC}), 12-\mathrm{O}$-tetradecanoyl phorbol-13-acetate (TPA), can induce expression of the ET gene by cultured endothelial cells [2]. Interestingly, the 5' flanking region of the structural ET gene contains two pair of the octanucleotide consensus sequence for "TPA-responsive elements" [3]. These cis-acting nucleotide sequences are binding sites for the complex of the protooncogene products c-JUN and c-FOS [4], suggesting that the activation of PKC by TPA may be functionally related to the activation of these

Received: October 9, 1991

Accepted: May 8, 1992

Correspondence to: Dr. Yoshiyuki HATTORI, Department of Endocrinology, Internal Medicine, Dokkyo University School of Medicine, Mibu, Tochigi 321-02, Japan. transcription factors, thereby having an effect on the ET gene. The involvement of PKC in stimulussecretion coupling has been described for many cell types and TPA has been shown to augment the secretion of ET by cultured endothelial cells [5]. However, the mechanism by which $\mathrm{PKC}$ regulates the release of ET remains elusive.

In this study, we examined the early and late effects of TPA on the basal and stimulated release of ET from cultured porcine aortic endothelial cells. We found that the early effect of TPA on the release of ET was stimulatory, whereas the late effect was inhibitory. Since a synthetic diacylglycerol mimicked the early effect of TPA and since pretreatment of cells with TPA suppressed ET release, it seems possible that PKC may be involved in regulationing the release of ET from cultured endothelial cells. 


\section{Materials and Methods}

Preparation of porcine aortic endothelial cells for culture was performed as described elsewhere [6]. The isolated endothelial cells were cultured in Dulbecco's modified Eagle's Medium (DMEM) containing $10 \%$ fetal calf serum (FCS) and antibiotics. This medium was replaced every three days. When the cells became confluent, they were used for the experiment.

To examine the effects of TPA (Sigma Chemical, St. Louis, MO) and 1-oleoyl-2-acetyl glycerol (OAG; Funakoshi Pharmaceuticals Co., Tokyo, Japan) on immunoreactive (IR)-ET-1 release, the cells were washed three times with fresh serumfree DMEM and were then incubated in the same medium with TPA or OAG for the indicated times at $37^{\circ} \mathrm{C}$.

To compare IR-ET-1 release by $\mathrm{PKC}$ down regulated cells and control cells, the cells were incubated in serum-free DMEM for $24 \mathrm{~h}$ at $37^{\circ} \mathrm{C}$ with or without $100 \mathrm{nM}$ TPA. The cells were then washed with fresh DMEM and were further incubated in medium containing thrombin (Sigma Chemical) or FCS for $4 \mathrm{~h}$.

After incubation, the culture media were collected and spun $(2,000 \times \mathrm{g} ; 20 \mathrm{~min})$; the supernatants were then removed and subjected to radioimmunoassay (RIA). Phase contrast microscopy did not detect any morphological changes in endothelial cells after incubation for $72 \mathrm{~h}$ under the various culture conditions used.

The RIA for porcine ET-1 was performed as described elsewhere [7]. Briefly, $50 \mu \mathrm{l}$ of the supernatant or standard porcine ET-1 (Peptide Institute Inc., Osaka, Japan) dissolved in the same culture medium was incubated with $50 \mu l$ (approximately $6,000 \mathrm{cpm}$ ) of 125I-ET-1 (specific activity, $74 \mathrm{TBq} / \mathrm{mmol}$; Amersham, Tokyo, Japan), $50 \mu l$ of rabbit anti-ET-1 serum (percent crossreactivity: ET-1, 100\%; ET-2,60\%; ET-3, 40\%; and big ET-1, <1\%; final dilution 1:8,000; Peptide Institute Inc.), and $50 \mu l$ of the assay buffer 50 $\mathrm{mM}$ phosphate buffer, $\mathrm{pH} 7.4$, containing $0.9 \%$ $\mathrm{NaCl}, 0.05 \% \quad \mathrm{NaN}_{3}$, and $0.5 \%$ bovine serum albumin). The mixture was incubated for $48 \mathrm{~h}$ at $4^{\circ} \mathrm{C}$. Following incubation, $200 \mu \mathrm{l}$ of $0.3 \%$ gammaglobulin in $50 \mathrm{mM}$ phosphate buffer and $1 \mathrm{ml}$ of $16 \%$ polyethyleneglycol in phosphate buffer were added, and the sample was centrifuged at $2,000 \times \mathrm{g}$ for $40 \mathrm{~min}$. Then the precipitate was counted in a gamma counter. The sensitivity of this ET-1 RIA was $5 \mathrm{pg} / \mathrm{tube}$ and the $50 \%$ intercept was at $55 \mathrm{pg} / \mathrm{tube}$. The intra-assay and interassay coefficients of variation were $6.1 \%$ $(n=12)$ and $8.2 \%(n=8)$, respectively.

\section{Results}

To observe the time course of IR-ET-1 release in the presence or absence of TPA, the cells were incubated in DMEM with or without TPA at $37^{\circ} \mathrm{C}$ for up to $72 \mathrm{~h}$. As shown in Fig. 1, IR-ET-1 release from the control cells (no TPA) increased according to time for up to $72 \mathrm{~h}$. In the presence of TPA, the release of IR-ET-1 was higher than the control level for up to $8 \mathrm{~h}$, but became lower thereafter and reached a plateau after $48 \mathrm{~h}$.

Figure 2 shows the effect of TPA $\left(10^{-7}-10^{-9}\right.$ M) on IR-ET-1 release after 4 or $72 \mathrm{~h}$ of incubation. TPA dose-dependently stimulated the

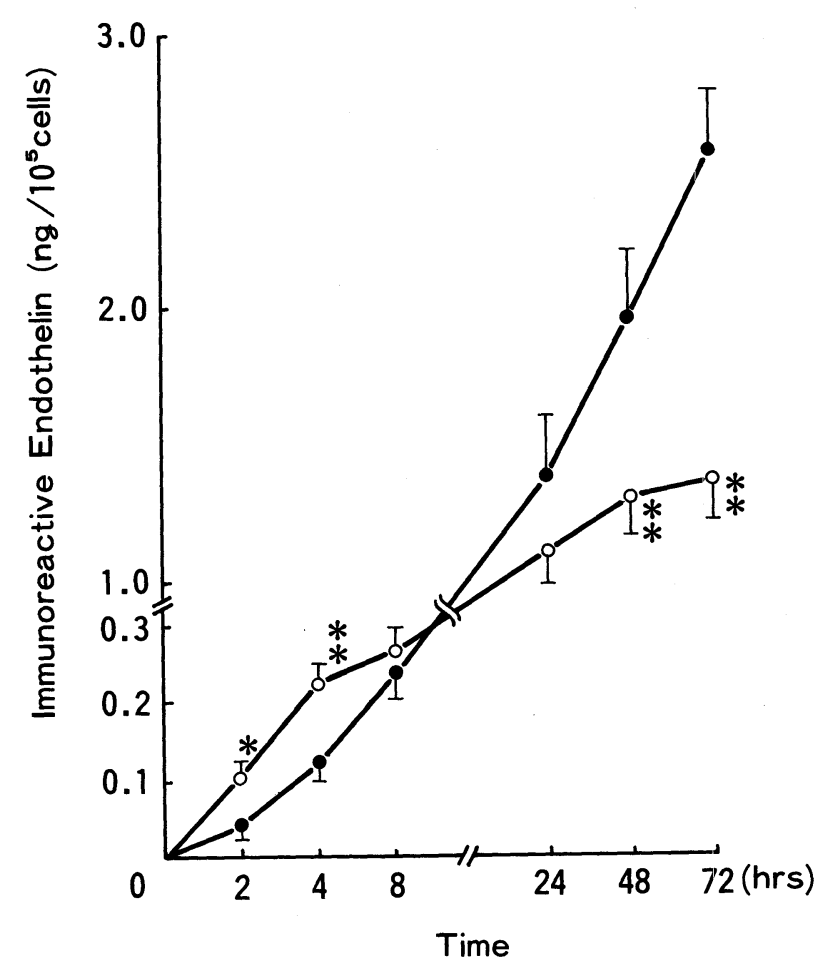

Fig. 1. Time course of IR-ET-1 release from endothelial cells. Cultured porcine aortic endothelial cells were incubated in DMEM (-) or DMEM plus TPA $\left(10^{-7} \mathrm{M}\right)(\mathrm{O}-\mathrm{O})$ for up to $72 \mathrm{~h}$. Each point represents the mean $\pm \mathrm{SD}$ of two experiments performed in triplicate. Cells incubated in the presence and absence of TPA were compared in each case. *, $P<0.05$; **, $P<0.01$, unpaired $t$-test. 


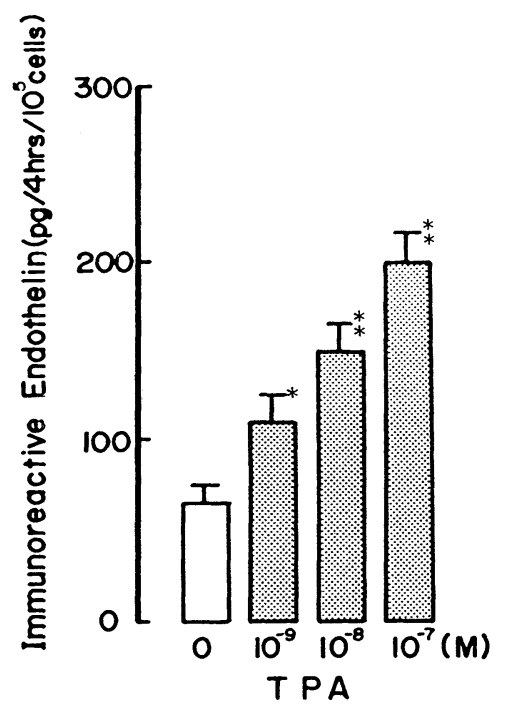

( A )

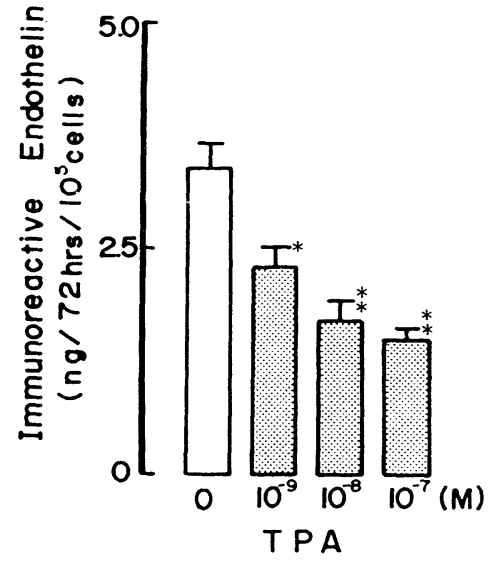

(B)

Fig. 2. Effect of TPA on IR-ET-1 release from endothelial cell. Cultured porcine aortic endothelial cells were incubated in DMEM containing various concentrations of TPA $\left(10^{-7}-10^{-9} \mathrm{M}\right)$ for $4 \mathrm{~h}(\mathrm{~A})$ and $72 \mathrm{~h}(\mathrm{~B})$. Data are expressed as the mean $\pm \mathrm{SD}$ of three experiments performed in triplicate. *, $P<0.05$; **, $P<0.01$, unpaired $t$-test.

release of IR-ET-1 after $4 \mathrm{~h}$ of incubation (Fig. 2A). However, after $72 \mathrm{~h}$ TPA dose-dependently suppressed the release of IR-ET-1 (Fig. 2B).

This demonstration of a dual effect of TPA on IR-ET-1 release raised the possibility that PKC activation was related to the stimulation of IR-ET1 release and that down-regulation of PKC led to the suppression of IR-ET-1 release. To test this possibility, we investigated the activation of PKC by $\mathrm{OAG}$, a synthetic diacylglycerol, to determine whether this activation mimicked the early action of TPA. We also assessed whether pretreatment of cells with TPA to down-regulate PKC depressed IR-ET-1 release. OAG stimulated IR-ET-1 release in a dose-dependent manner $(5-500 \mu \mathrm{M})$ after $4 \mathrm{~h}$ of incubation (Fig. 3). Basal and thrombin- or FCS-stimulated IR-ET-1 release was suppressed by $32 \%, 34 \%$, and $26 \%$, respectively, in TPApretreated cells after $4 \mathrm{~h}$ of incubation (Fig. 4).

\section{Discussion}

The involvement of PKC in stimulationsecretion coupling related to the production and release of aldosterone [8], insulin [9], catecholamine [10], and atrial natriuretic peptide [11] has

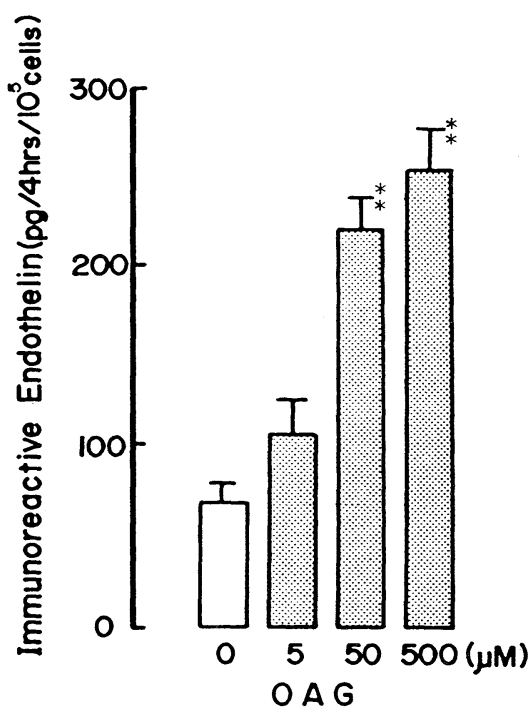

Fig. 3. Effect of OAG on IR-ET-1 release from endothelial cells. Cultured porcine aortic endothelial cells were incubated in DMEM containing various concentrations of OAG $(5-500 \mu \mathrm{M})$ for 4 h. Data are expressed as the mean $\pm \mathrm{SD}$ of three experiments performed in triplicate. $* *, P<0.01$, unpaired $t$-test. 


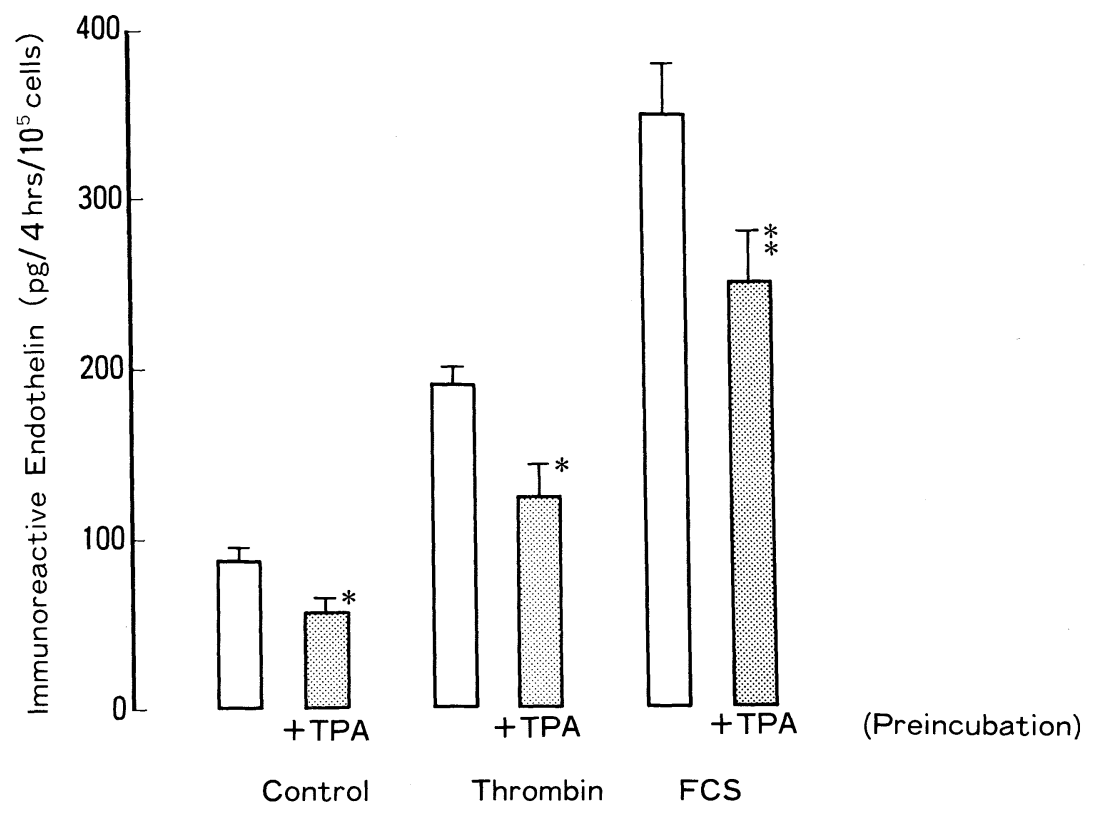

Fig. 4. Effects of preatratment of endothelial cells with TPA to down-regulate PKC on IR-ET-1 release. Cultured porcine aortic endothelial cells were preincubated in DMEM containing $10^{-7} \mathrm{M}$ TPA for $24 \mathrm{~h}$, and were then incubated for a further $4 \mathrm{~h}$ in DMEM alone or DMEM containing $1 \mu / \mathrm{m} l$ of thrombin or $10 \%$ FCS. Data are expressed as the mean \pm SD of three experiments performed in triplicate. $*, P<0.01 ; * *, P<0.01$, unpaired $t$-test.

been well described in many types of cells. PKC also appears to have various other biological roles in endothelial cells, and this study showed that changes in ET-1 release were related to the activation and down-regulation of PKC.

The amount of IR-ET- 1 in the culture medium closely reflected ET-1 release from the endothelial cells, since the cross-reactivity with big ET-1 of the antiserum used in our RIA was very low. Moreover, a good correlation between serial dilutions of culture medium and dilution of synthetic ET-1 has been obtained with this RIA, and the correspondence of IR-ET-1 in culture medium with synthetic ET-1 has been observed by reversed-phase high performance liquid chromatography [7].

The present experiments demonstrated that TPA can regulate the release of ET-1 from cultured porcine endothelial cells. TPA had a dose-dependent effects on IR-ET-1 release with its initial effect being stimulatory and its late effect being inhibitory. This dual effect of TPA on IR-ET-1 release is in agreement with the marked changes in the expression of ET-1 mRNA after the addition of TPA [2]. These results raise the possibility that the activation of PKC stimulated ET-1 release, while the persistent activation and subsequent down-regulation of PKC led to the suppression of ET-1 release.

If the binding of TPA to PKC initially stimulates the release of ET-1 through the activation of this enzyme, then diacylglycerol which is known to stimulate PKC ought to produce the same effect. In fact, we found that synthetic diacylglycerol (OAG), which can activate platelet PKC activity in situ [12], dose-dependently increased the release of IR-ET- 1 after $4 \mathrm{~h}$ of incubation in the same way that TPA did. These data suggest that OAG mimicked the early action of TPA and stimulated ET-1 release via the activation of PKC.

We also investigated whether down-regulation of PKC by pretreatment of endothelial cells with a high dose of TPA altered IR-ET-1 release. Uratsuji et al. reported that when porcine aortic endothelial cells were treated with $200 \mathrm{nM}$ TPA for $24 \mathrm{~h}$, the PKC activity of the cells disappeared completely [13]. Although PKC levels in the cells were not measured after treatment with $100 \mathrm{nM}$ TPA for 24 $\mathrm{h}$, the alteration in IR-ET-1 release caused by the down-regulation of PKC could be assessed under these culture conditions. Compared with cells incubated without TPA, the cells incubated in TPA-containing medium released significantly less 
IR-ET-1 under both basal and thrombin- or FCS-stimulated conditions. This suggests that pretreatment of cells with a high dose of TPA mimicked the late action of TPA and suppressed ET-1 release, possibly through the downregulation of PKC. However, persistent activation of PKC can induce alterations not only of signal transduction but also of the differentiation or proliferation of cells and such changes may be involved in the suppression of ET-1 release.

ET-1 produced in vascular endothelial cells from approximately 200-residue prepropeptide via a 39 (porcine)-residue intermediate called big ET-1. Big ET-1 is converted to active ET-1 via proteolysis. Therefore, the effect of TPA on this proteolytic process needs to be taken into consideration when assessing the results of the present study. However, since we could detect only a very small amount of big ET-1 in the culture medium in the presence or absence of TPA, we could not determine the effect of TPA on the proteolytic processing of ET-1. This remains to be established in further studies.

The present study suggested that PKC plays an important role in regulating the production and release of ET-1 by endothelial cells. The release of ET-1 requires de novo protein synthesis, as demonstrated by the finding that a protein synthetase inhibitor (cycloheximide) markedly inhibited the release of this peptide (data not shown). In addition, the time course of the release of IR-ET-1 appears to be compatible with the production of this peptide rather than with its release from intracellular stores. Therefore, the regulation of ET-1 release by $\mathrm{PKC}$ is likely to be due to alterations in the production of this peptide. However, further research is still necessary to elucidate the mechanism of ET-1 release, especially in regard to its relationship with PKC activity.

\section{References}

1. Yanagisawa $M$, Kiura $H$, Kimura $S$, Tomobe $Y$, Kobayashi M, Mitsui Y, Yazaki Y, Goto K, Masaki $\mathrm{T}$ (1988) A noval potent vasoconstrictor peptide produced by vascular endothelial cells. Nature 332: $411-415$

2. Yanagisawa M, Inoue A, Takuwa $\mathrm{Y}$, Mitsui $\mathrm{Y}$, Kobayashi M, Masaki T (1989) The human preproendothelin-1 gene: Possible regulation by endothelial phosphoinositide turnover signaling. $J$ Cardiovasc Pharmacol 13 (Suppl. 5): S13-17.

3. Lee W, Mitchell P, Tjian R (1987) Purified transcription factor AP-1 interacts with TPA-inducible enhancer elements. Cell 49: 741-752.

4. Rauscher FJ, Cohen DR, Curran T, Bos TJ, Vogt PK, Bohmann D, Tjian R, Franza BR (1988) Fos-associated protein $\mathrm{p} 39$ is the product of the jun proto-oncogene. Science 240: 1010-1016.

5. Emori T, Hirata Y, Ohta K, Shichiri M, Marumo F (1989) Secretory mechanism of immunoreactive endothelin in cultured bovine endothelial cells. Biochem Biophys Res Commun 160: 93-100.

6. Hattori Y, Kasai K, Emoto T, Hiraiwa M, Shimoda S (1990) The inhibitory effect of cyclosporine on prostacyclin production by cultured endothelial cells from porcine aorta. Transplant Proc 21: 3461-3463.

7. Hattori $Y$, Kasai $K$, Nakamura $T$, Emoto $T$, Shimoda S (1991) The effect of glucose and insulin on immunoreactive endothelin-1 release from cul- tured porcine aortic endothelial cells. Metabolism 40: 165-169.

8. Kojima I, Lippes H, Kojima K, Rausmussen H (1983) Aldosterone secretion: effect of phorbol ester and A23187. Biochem Biophys Res Commun 116: 555-562.

9. Zawalich W, Brown C, Rausmussen H (1983) Insulin secretion: combined effects of phorbol ester and A23187. Biochem Biophys Res Commun 117: 448-455.

10. Pocotte SL, Frye RA, Senter RA, TerBush DR, Lee SA, Holz RW (1985) Effect of phorbol ester on catecholamine secretion and protein phosphorylation in adrenal medullary culture. Proc Natl Acad Sci USA 82: 930-944.

11. Ruskoaho H, Toth M, Lang RE (1985) Atrial natriuretic peptide secretion: synergistic effect of phorbol ester and A23187. Biochem Biophys Res Commun 133: 581-588.

12. Kaibuchi K, Takai Y, Sawamura M, Hoshijima M, Fujikawa T, Nishizuka Y (1983) Synergistic functions of protein phosphorylation and calcium mobilization in platelet activation. J Biol Chem 258: 6701-6701.

13. Uratsuji Y, Dicorleto PE (1988) Growth-dependent subcellular redistribution of protein kinase $\mathrm{C}$ in cultured porcine aortic endothelial cells. J Cell Physiol 136: 431-438. 